Published at Jorunal of Inorganic Biochemistry 126 (2013) 61-69

\title{
A minimalist chemical model of matrix metalloproteinases- Can small peptides mimic the more rigid metal binding sites of proteins?
}

Dávid Árus ${ }^{\mathrm{a}}$, Nóra Veronika Nagy ${ }^{\mathrm{b}}$, Ágnes Dancs ${ }^{\mathrm{c}}$, Attila Jancsóc ${ }^{\mathrm{c}}$, Róbert Berkecz ${ }^{\mathrm{d}}$, Tamás Gajda ${ }^{\mathrm{c}, *}$

${ }^{a}$ Bioinorganic Chemistry Research Group of the Hungarian Academy of Sciences, University of Szeged, Szeged, Hungary

${ }^{b}$ Institute of Molecular Pharmacology, Research Centre for Natural Sciences, Hungarian Academy of Sciences, Budapest, Hungary

${ }^{c}$ Department of Inorganic and Analytical Chemistry, University of Szeged, Szeged, Hungary

${ }^{d}$ Department of Medical Chemistry, University of Szeged, Szeged, Hungary

\section{Abstract}

In order to develop a minimalist chemical model of matrix metalloproteinases (MMPs), we synthesized a pentadecapeptide (Ac-KAHEFGHSLGLDHSK-NH ${ }_{2}$ ) corresponding to the catalytic zinc(II) binding site of human MMP-13. The multi-domain structural organization of MMPs fundamentally determines their metal binding affinity, catalytic activity and selectivity. Our potentiometric, UV-VIS, CD, EPR, NMR, ESI-MS and kinetic study are aimed to explore the usefulness of flexible peptides to mimic the more rigid metal binding sites of proteins, to examine the intrinsic metal binding properties of this naked sequence, as well as to contribute the development of a minimalist, peptide-based chemical model of MMPs, including the catalytic properties. Since multiimidazole environment is also characteristic for copper(II), and recently copper(II) containing variants of MMPs have been identified, we also studied the copper(II) complexes of the above peptide.

Around $\mathrm{pH}$ 6-7 the peptide, similarly to MMPs, offers $\left\{3 \mathrm{~N}_{\mathrm{im}}\right\}$ coordinated binding site for both zinc(II) and copper(II). In the case of copper(II), the formation of amide coordinated species at higher $\mathrm{pH}$ ceased the analogy with the copper(II) containing MMP variant. On the other hand, the zinc(II)-peptide system mimics some basic features of the MMP active sites: the main species around $\mathrm{pH} 7\left(\mathrm{ZnH}_{2} \mathbf{L}\right)$ possesses $\left\{3 \mathrm{~N}_{\mathrm{im}}, \mathrm{H}_{2} \mathrm{O}\right\}$ coordination environment, the deprotonation of the zinc-bound water takes place near to the physiological $\mathrm{pH}$, it forms relatively stable ternary complexes with hydroxamic acids, and the species $\mathrm{ZnH}_{2} \mathbf{L}(\mathrm{OH})$ and $\mathrm{ZnH}_{2} \mathbf{L}(\mathrm{OH})_{2}$ have notable hydrolytic activity between $\mathrm{pH}$ 7-9. 
*Corresponding author.

E-mail: gajda@chem.u-szeged.hu (T. Gajda),Tel.: (+36)-62-544435, Fax: (+36)-62-544340 


\section{Introduction}

The metal binding side chains in metalloproteins are generally far-away from each other in the primary sequences, they are often separated by more than hundred amino acids. Such metal binding sites are obviously difficult to mimic by small peptides. However, a number of proteins possess relatively short histidine-rich sequences with strong metal binding ability, which substantially contributes to the function of the given macromolecule [1-18]. Beside the well known human serum albumin (HSA) [1], probably the prion proteins ( $\operatorname{PrP})$ [2] are the most studied examples of such sequences. Studies on the metal ion binding of peptides related to the N-terminal of HSA [3-5], and those mimicking the octarepeat region of PrP [6-8] demonstrated the usefulness of such studies. Besides, several peptides copying the putative metal binding sequences of e.g. human $\alpha$-synuclein [9], human endostatin [10], bacterial superoxide dismutases [11,12] and E. coli SlyD protein [13] have been studied to uncover fine functional details of the corresponding proteins. However, these metal binding sequences are part of less structured regions, frequently at the N-terminals, which may allow closer analogy in the metal binding properties of model peptides and native proteins.

Sequences within the polypeptide chains are generally more rigid due to the tertiary structure of the proteins, which provides preorganized binding site for the metal ion(s) in metalloproteins. In spite of the short sequences, such preorganization obviously reduces the analogy with a more flexible oligopeptides. Nevertheless, a number of studies are reported in the literature dealing with short in-chain sequences as putative metal binding sites of e.g. amyloid precursor protein [14], the repeat sequences of Cap43 [15] and histidine-rich (glyco)proteins [16], the histon H2A protein [17] or the metal-transport protein IRT1 [18]. In spite of the limited analogy between such peptides and the native proteins, in the absence of structural information such studies are of great values, since even the identification of putative metal binding sites may improve our knowledge on the functioning of the given proteins. 
In this context it would be interesting to examine such peptide-protein analogy from a reverse point of view, i.e. studying a relatively short, flexible peptide corresponding to the metal binding site of a structurally well characterized metalloprotein. In this way one would explore the usefulness of peptides, lacking the structural stabilization determined by the tertiary structure, to mimic preorganized metal binding sites of proteins. For this end, the consensus catalytic metal binding sequence of matrix metalloproteinases (MMPs) is well suited. These enzymes are responsible for remodelling of connective tissues, and are essential for e.g. embryonic development, cell growth, proliferation, and wound repair. MMPs are also implicated in a number of pathological processes, such as arthritis, cardiovascular and neurological diseases, tumour cell invasion and metastasis. Consequently, these enzymes are important therapeutic targets for the treatment of the above diseases [19]. Matrix metalloproteinases contain two zinc ions, one has catalytic the other has structural role. The N-terminally located catalytic domain of MMPs are characterized by a well conserved

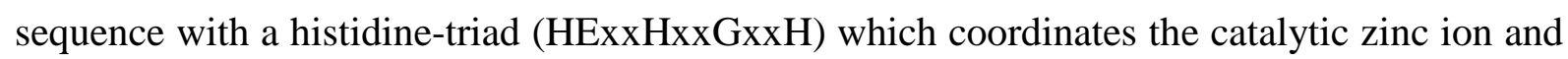
contains the glutamate residue that is also critical for catalysis. The catalytic zinc is coordinated by three imidazole nitrogens and a water molecule [20].

In this study we report the coordination properties of a pentadecapeptide (AcKAHEFGHSLGLDHSK-NH 2 , L) corresponding to the catalytic zinc(II) binding site (197213) of human MMP-13 [21], except the first position where the valine has been replaced by lysine in order to increase the water solubility of the peptide and its metal complexes. Our potentiometric, UV-VIS, CD, EPR, NMR, ESI-MS and kinetic study are aimed to explore the intrinsic properties of this naked, virtually unstructured metal binding sequence, as well as to contribute the development of a minimalist, peptide-based chemical model of MMPs, including the catalytic properties and the binding to hydroxamic acids, as model of MMP inhibitors [22]. Since the multiimidazole environment is also characteristic for copper(II), and 
recently copper(II) containing variants of MMPs have been identified in Volvox carteri [23], for comparative purposes we also studied the copper(II) complexes of the peptide.

\section{Materials and methods}

Copper(II) and zinc(II) chloride solutions were prepared from analytically pure compounds (Fluka) and standardized complexometrically. $\mathrm{pH}$-metric titrations were performed by $0.1 \mathrm{M}$ $\mathrm{NaOH}$ (Fluka) standard solution. Fmoc-amino acids, 2-(1H-benzotriazole-1-yl)-1,1,3,3tetramethyluronium hexafluorophosphate (HBTU) and N-hydroxybenzotriazole (HOBt) were purchased from Novabiochem. N,N-diisopropylethylamine (DiPEA), diethylether (Sigma), triisopropylsilane, piperidine (Aldrich), pyridine (Merck), acetic anhydride (Fluka), trifluoroacetic acid (Riedel-de Haën), N,N-dimethyl-formamide (DMF), dichloromethane, methanol (Molar Chemicals), and acetonitrile (Scharlau) were analytically pure chemicals and used without further purification.

\subsection{Synthesis of Ac-KAHEFGHSLGLDHSK-NH $\mathrm{H}_{2}$ peptide (L)}

The peptide was prepared by solid phase peptide synthesis using the Fmoc methodology $($ Fmoc $=9$-fluorenylmethoxycarbonyl). Tentagel S RAM $0.25 \mathrm{mmol} / \mathrm{g}($ Iris Biotech $\mathrm{GmbH})$ was used as a solid support. The amino acid building blocks were applied in 4-fold excess over the capacity of the resin. The amino acid residues were coupled to each other (and to the resin) by applying HBTU (4 eq./building block), HOBt (4 eq./building block) and N,Ndiisopropylethylamine (8 eq./building block) in DMF. The Fmoc-protecting groups were removed by using a solution of $20 \%$ piperidine in DMF. The usual coupling reaction time was $1 \mathrm{~h}$. The attachment of each amino acid residues was monitored by Kaiser-test [24] and by the detection of the cleaved Fmoc group at $290 \mathrm{~nm}$ in DMF. In the case of successful coupling the free residual amino nitrogens were acetylated with the mixture of acetic anhydride, 
dichloromethane and diisopropylethylamine (10-80-10\%). After the last coupling step the resin was rinsed by dichloromethane and methanol, and then it has been dried. Cleavage of the peptide from the resin was performed in the mixture of TFA, $\mathrm{H}_{2} \mathrm{O}$ and triisopropylsilane (95-2.5-2.5\%). The peptide was preciptated with diethyl ether, re-dissolved in water and freeze-dried. The crude product was purified by RP-HPLC (Shimadzu LC-20) using a Supelco Discovery BIO Wide Pore C18 $(250 \times 10 \mathrm{~mm}, 5 \mu \mathrm{m})$ semi preparative column. The compound was eluted by using the mixtures of water containing $0.1 \%$ TFA and acetonitrile (Eluent A: $99.9 \% \mathrm{H}_{2} \mathrm{O}, 0.1 \%$ TFA, Eluent B: $99.9 \% \mathrm{CH}_{3} \mathrm{CN}, 0.1 \%$ TFA) with a $3 \mathrm{~mL} / \mathrm{min}$ flow rate and applying the following gradient program: 0-5 min $12 \% \mathrm{~B} ; 5-17 \min 12-14 \% \mathrm{~B}$ (linear gradient); 17-25 min 14-18\% B (linear gradient); 25-40 min 18-70\% B (linear gradient); 40-45 min 70-12 \% B (linear gradient); $\left(\mathrm{R}_{\mathrm{t}}=13.4 \mathrm{~min}\right)$. After purification the ligand was obtained as a trifluoroacetate salt, the yield was 53.0\%. The HPLC chromatogram of the purified peptide is depicted in Fig. S1 (see Supplementary Data).

The peptide was identified by ESI-MS: $\mathrm{m} / \mathrm{z}=852.45[\mathrm{M}+2 \mathrm{H}]^{2+}$ and $\mathrm{m} / \mathrm{z}=568.63[\mathrm{M}+$ $3 \mathrm{H}]^{3+}$. The calculated monoisotopic molecular mass is: $1702.85 \mathrm{Da}$. The purity was also confirmed by potentiometry and NMR spectroscopy.

\subsection{Potentiometric measurements}

The protonation and coordination equilibria were investigated by potentiometric titrations in aqueous solution $(I=0.1 \mathrm{M} \mathrm{NaCl}$, and $T=298.0 \pm 0.1 \mathrm{~K})$ under argon atmosphere, using an automatic titration set including a PC controlled Dosimat 665 (Metrohm) autoburette and an Orion 710A precision digital $\mathrm{pH}-$ meter. The Metrohm Micro pH glass electrode (125 mm) was calibrated [25] via the modified Nernst equation:

$$
E=E_{0}+K \cdot \log \left[\mathrm{H}^{+}\right]+J_{\mathrm{H}} \cdot\left[\mathrm{H}^{+}\right]+\frac{J_{\mathrm{OH}} \cdot K_{\mathrm{w}}}{\left[\mathrm{H}^{+}\right]}
$$


where $J_{\mathrm{H}}$ and $J_{\mathrm{OH}}$ are fitting parameters in acidic and alkaline media for the correction of experimental errors, mainly due to the liquid junction and to the alkaline and acidic errors of the glass electrode; $K_{\mathrm{w}}=10^{-13.75} \mathrm{M}^{2}$ is the autoprotolysis constant of water at $298 \mathrm{~K}$ [26]. The parameters were calculated by the non-linear least squares method. The complex formation was characterized by the following general equilibrium process:

$$
\begin{aligned}
& \mathrm{pM}+\mathrm{qH}+\mathrm{rL}+\mathrm{sB} \stackrel{\beta_{\mathrm{M}_{\mathrm{p}} \mathrm{H}_{\mathrm{q}} \mathrm{L}_{\mathrm{r}}}^{\longrightarrow}}{\longrightarrow} \mathrm{M}_{\mathrm{p}} \mathrm{H}_{\mathrm{q}} \mathrm{L}_{\mathrm{r}} B_{s} \\
& \beta_{\mathrm{M}_{\mathrm{p}} \mathrm{H}_{\mathrm{q}} \mathrm{L}_{\mathrm{r}} B_{s}}=\frac{\left[\mathrm{M}_{\mathrm{p}} \mathrm{H}_{\mathrm{q}} \mathrm{L}_{\mathrm{r}} B_{s}\right]}{[\mathrm{M}]^{\mathrm{p}}[\mathrm{H}]^{\mathrm{q}}[\mathrm{L}]^{\mathrm{r}}[B]^{s}}
\end{aligned}
$$

where $\mathrm{M}$ denotes the metal ion and $\mathrm{L}$ and $\mathrm{B}$ the non-protonated peptide and benzohydroxamic acid molecules, respectively. Charges are omitted for simplicity, but can be easily calculated taking into account the composition of the fully protonated ligands $\left(\mathrm{H}_{7} \mathrm{~L}^{5+}\right.$ and $\left.\mathrm{HB}\right)$. The corresponding formation constants $\left(\beta_{\mathrm{M}_{\mathrm{p}} \mathrm{H}_{\mathrm{q}} \mathrm{L}_{\mathrm{r}} \mathrm{B}_{\mathrm{s}}} \equiv \beta_{\mathrm{pqrs}}\right)$ were calculated using the PSEQUAD computer program [27].

The protonation constants were determined from 4 independent titrations (90 data points per titration), with peptide concentration $1-1.5 \times 10^{-3} \mathrm{M}$. The complex formation constants were evaluated from 7 and 9 independent titrations (70-90 data points per titration) in case of the zinc(II) and copper(II) containing systems, respectively. The metal-to-ligand ratios were 2:1, 1:1 and 1:2 (in case of zinc(II) precipitation occurred above $\mathrm{pH} 7$ at twofold metal ion excess). The metal ion concentrations varied between $0.6-2.9 \times 10^{-3} \mathrm{M}$. The titrations were performed between $\mathrm{pH} 2.6$ and 11.4, but due to the rather low concentrations of the peptide ($\log \mathrm{c}_{\text {peptide }}=2.5-3.2$ ), the derived equilibrium data of the processes below $\mathrm{pH} 3.6$ and above pH 10.4 have increased uncertainties.

\subsection{Electronic absorption and CD measurement}


UV-Vis spectra were measured on a Unicam Helios $\alpha$ spectrophotometer using a cell with 1 cm optical pathlength. The CD spectra were recorded on a Jasco J-710 spectropolarimeter in the wavelength interval from 300 to $800 \mathrm{~nm}$ in a cell with $1 \mathrm{~cm}$ optical pathlength. The metal ion concentration was varied between $0.8-2.8 \times 10^{-3} \mathrm{M}$, depending on the metal-to-ligand ratio. For the copper(II) containing systems the $\mathrm{pH}$-dependent UV-Vis spectra were treated together with $\mathrm{pH}$-potentiometric data using the computer program PSEQUAD [27], resulting the formation constants $\left(\beta_{\mathrm{pqr}}\right)$ and the individual UV-Vis spectra of the copper(II) complexes. The individual CD spectra were also calculated by PSEQUAD.

\subsection{EPR and NMR measurements}

The EPR spectra were recorded at $77 \mathrm{~K}$ using a BRUKER EleXsys E500 spectrometer. All recorded EPR spectra in the systems were simulated with a spectrum decomposition method by a computer program [28]. Since the copper(II) salt used to make the stock solution was a natural mixture of the isotopes, the spectrum of each species was calculated as the sum of spectra containing ${ }^{63} \mathrm{Cu}$ and ${ }^{65} \mathrm{Cu}$ weighted by their abundances in nature. The copper and ligand coupling constants are given in units of gauss $\left(1 \mathrm{G}=10^{-4} \mathrm{~T}\right)$.

${ }^{1} \mathrm{H}$ NMR measurements were performed on a Bruker Avance DRX 500 spectrometer. The spectra were recorded at $25{ }^{\circ} \mathrm{C}$ in $100 \% \mathrm{D}_{2} \mathrm{O}$ solution, at a peptide concentration of 3.0 $6.0 \times 10^{-3} \mathrm{M}$ (the tube diameter was $5 \mathrm{~mm}$ ). The $\mathrm{pH}$ was adjusted to the desired values with NaOD. 2D COSY, TOCSY and ROESY spectra were acquired with 2048(F2)×1024(F1) complex points. The TOCSY experiments employed the MLEV17 sequence with a mixing time of $75 \mathrm{~ms}$. ROESY spectra were acquired with mixing times of $300 \mathrm{~ms}$. The chemical shifts $\delta$ were measured with respect to dioxane as internal reference and converted relative to $\mathrm{SiMe}_{4}$, using $\delta_{\text {dioxane }}=3.70$. Data were processed using the Topspin 2.0 software package (Bruker). 


\subsection{Mass spectrometric measurements}

Mass spectrometry was performed on a Waters Micromass ${ }^{(\mathrm{R})}$ Q-TOF Premier mass spectrometer operating in negative and positive mode using electrospray source (ESI). The samples were dissolved in methanol(90\%)-water(10\%) mixture and transferred into a mass spectrometer by direct infusion at a flow rate of $10 \mu \mathrm{l} / \mathrm{min}$. The capillary and cone voltages were set to (+,-) $3.3 \mathrm{kV}$ and (+,-) $26 \mathrm{~V}$. The desolvation temperature was set to $150{ }^{\circ} \mathrm{C}$ and the source temperature to $85{ }^{\circ} \mathrm{C}$. The cone gas was at a flow rate of $50 \mathrm{~L} / \mathrm{h}$, whereas the desolvation gas flow was maintained at $200 \mathrm{~L} / \mathrm{h}$. For qualitative analysis the identified copper complex ions were detected in an MS survey scan of $1 \mathrm{~s}$ from an m/z of 50 to $1990 \mathrm{using} 5$ eV collision energy. The TOF was calibrated on daily basis using sodium-formate solution in negative and positive mode and subsequently operated at high accuracy $(<5 \mathrm{ppm})$ without utilizing reference masses. All data were acquired and theoretical isotope patterns were determined by MassLynx V4.1 software (Waters Inc.).

\subsection{Kinetic study}

The hydrolysis of $p$-nitrophenyl acetate (pNPA) was followed in a buffered aqueous solution containing $10 \% \mathrm{CH}_{3} \mathrm{CN}(\mathrm{I}=0.1 \mathrm{M} \mathrm{NaCl}, \mathrm{T}=298 \mathrm{~K})$ by detecting the increase in absorption maximum at $400 \mathrm{~nm}$ of the $p$-nitrophenolate anion $(\varepsilon=18900, \mathrm{pK}=6.98(2))$. In all cases 0.04 M buffer (MES, HEPES, CHES) was used to maintain the $\mathrm{pH}$. The initial concentration of NPA varied from 0.9 to $12 \mathrm{mM}$. The reported kinetic data, determined by the initial slope method ( $\leq 3 \%$ conversion) are averages of duplicate measurements (reproducibility better than $\pm 5 \%$ ). In a typical experiment, the $\mathrm{pH}$ of the solution containing $0.5 \mathrm{mM}$ ligand zinc(II) was adjusted to the desired $\mathrm{pH}$ value. $1.8 \mathrm{~mL}$ of this solution was equilibrated at $298 \mathrm{~K}$ in the spectrophotometer, then $0.2 \mathrm{~mL}$ of freshly prepared $0.02 \mathrm{M}$ pNPA in $\mathrm{CH}_{3} \mathrm{CN}$ was injected 
into the solution with efficient mixing. The increase of the absorbance at $400 \mathrm{~nm}$ was immediately followed. The $\mathrm{pH}$ of the mixture was checked after every kinetic run.

\section{Results and Discussion}

The studied pentadecapeptide $\mathbf{L}$ has seven groups able to (de)protonate between $\mathrm{pH}=2-11$ (2 Lys, 3 His, 1-1 Glu and Asp). The protonation constants and the corresponding $\mathrm{pK}$ values are listed in Table 1. $\mathrm{pK}_{1}$ and $\mathrm{pK}_{2}$ belong to the carboxylate groups. The pKs related to the imidazole rings $\left(\mathrm{pK}_{3,4,5}=5.86-6.99\right.$, Table 1$)$ are in the range generally observed for Hiscontaining peptides. Since these deprotonations are strongly overlapped, the values in Table 1 are macroscopic constants and cannot be related to individual histidine residues. Above $\mathrm{pH} 10$ the deprotonations of the two lysine $\varepsilon-\mathrm{NH}_{3}{ }^{+}$take place, also in an overlapping manner. Due to the relatively low peptide concentration applied in our measurements the $\mathrm{pK}<3.6$ and $\mathrm{pK}>$ 10.4 values have somewhat higher uncertainties than usual for $\mathrm{pH}$-potentiometric studies (see also the experimental part).

\subsection{Zinc(II) complexes}

In equimolar solution of zinc(II) and $\mathbf{L}$, a series of differently protonated complexes were detected between $\mathrm{pH} 4$ and 11. As a consequence of the positively charged $\mathrm{N}$ - and $\mathrm{C}$-terminal lysine residues, precipitate formation, which is very frequent in presence of zinc(II) and Nprotected peptides [29,30], was not observed. Around $\mathrm{pH} 7$ the diprotonated complex $\mathrm{ZnH}_{2} \mathbf{L}$ is dominant in the solution (Figure 1). This is corroborated with the ESI-MS results (Figure 2), which indicated the formation of water adduct of these species at $\mathrm{m} / \mathrm{z} 601.3$ $\left(\left[\mathrm{ZnH}_{3} \mathbf{L}+2 \mathrm{H}_{2} \mathrm{O}\right]^{3+}\right)$ and at $\mathrm{m} / \mathrm{z} 901.4\left(\left[\mathrm{ZnH}_{2} \mathbf{L}+2 \mathrm{H}_{2} \mathrm{O}\right]^{2+}\right) .{ }^{1} \mathrm{H}$ NMR investigations have been performed to identify the metal binding sites in the formed complexes. The assignment of the proton signals was based on COSY, TOCSY and ROESY experiments. The $\mathrm{pH}$ dependence 
of the signals in equimolar solution of zinc(II) and peptide is shown in Figure 3. The shift of $\mathrm{C} 2-\mathrm{H}$ and $\mathrm{C} 5-\mathrm{H}$ signals of the imidazole rings upon complex formation, especially at $\mathrm{pH} 6$, indicates that the three imidazole rings are coordinated in $\mathrm{ZnH}_{2} \mathbf{L}$. The changes of the ${ }^{1} \mathrm{H}$ NMR spectra of the peptide at pH 7 upon addition of zinc(II) are depicted in Figure 4. The signals of the two terminal lysines do not shift, remain sharp and well resolved, suggesting that they are protonated in $\mathrm{ZnH}_{2} \mathbf{L}$. However, unexpectedly strong broadening has been observed for most amino acid residues, including those containing non-coordinating side chains, such as Phe and Gly. This indicates intermediate exchange between the free and bound peptide. In addition, the fact that all central residues of the pentadecapeptide are affected upon zinc(II) binding, i.e. no freely rotating part of the molecule is present apart the terminal lysines, indirectly suggests the coordination of the three histidine side chains, too. On the other hand, besides the broadening, the signals related to the two leucine residues are also shifted upon complex formation, and their methyl groups become inequivalent in the complexes (Figs. 3 and 4). This indicates conformational changes of the peptide during the formation of the two macrochelates between the three coordinated imidazole rings.

The stability constant of $\mathrm{ZnH}_{2} \mathbf{L}\left(\mathrm{Zn}^{2+}+\mathrm{H}_{2} \mathbf{L}=\mathrm{ZnH}_{2} \mathbf{L}, \log \mathrm{K}_{1}=4.46\right)$ is somewhat lower than those of some $\left\{3 \mathrm{~N}_{\mathrm{im}}\right\}$ coordinated zinc-peptide complexes (log $\mathrm{K}=5.09$ for AcHVHAH-NH $\mathrm{N}_{2}$ [31], $\log \mathrm{K}=4.64$ for Ac-HAAHVVH-NH ${ }_{2}$ [30]), due to the larger macrochelate rings formed between the imidazole rings in the present case. The lower stability also suggests that additional coordination of carboxylate groups can be neglected. The unsaturated coordination sphere in $\mathrm{ZnH}_{2} \mathbf{L}$ results in the formation of bis-complex $\left(\mathrm{Zn}\left(\mathrm{H}_{2} \mathbf{L}\right)_{2}\right)$ in the presence of ligand excess. The value of $\log \left(\mathrm{K}_{1} / \mathrm{K}_{2}\right)=0.88$ indicates identical binding of the two ligands in the bis-complex.

Increasing the $\mathrm{pH}$ above 7 , the complex $\mathrm{ZnH}_{2} \mathbf{L}$ releases four additional protons with $\mathrm{pK}=7.59,8.60,10.06$ and 10.66, respectively (Table 1, Figure 1). New peaks reflecting slow 
exchange between the free and bound ligand, observed earlier for amide-coordinated zinc(II) complexes of Gly-His, Ala-His and Gly-His-Lys [32,33], were not detected on the ${ }^{1} \mathrm{H}$ NMR spectra up to $\mathrm{pH} 8.8$ (Figure 3), suggesting that zinc(II) promoted deprotonation of amide nitrogen(s) is unlikely. Moreover, the peaks related to ${ }^{1} \mathrm{Lys} /{ }^{15} \mathrm{Lys}$ are unchanged upon zinc(II) binding, indicating that these residues are still protonated. Consequently, the first two deprotonations are related to the formation of mixed hydroxo complexes $\left(\mathrm{ZnHL}=\mathrm{Zn}\left(\mathrm{H}_{2} \mathbf{L}\right)(\mathrm{OH})\right.$ and $\left.\mathrm{Zn} \mathbf{L}=\mathrm{Zn}\left(\mathrm{H}_{2} \mathbf{L}\right)(\mathrm{OH})_{2}\right)$, similarly to many other zinc(II)-peptide systems $[11,16,34]$. During the last two processes the deprotonation of the Lys residues take place. Indeed, the observed pKs are close to those of the lysine residues in the absence of zinc(II) (Table 1).

Since hydroxamic acids are well known inhibitors of MMPs, operating by coordination to the catalytic zinc, we also studied the complex formation in the zinc(II)-Lbenzohydroxamic acid (B) ternary system. The formation constants determined for the binary zinc(II)-B complexes (Table 2) are close to those determined earlier [35,36]. Only two ternary species can be detected $\left(\mathrm{Zn}\left(\mathrm{H}_{3} \mathbf{L}\right) \mathbf{B}\right.$ and $\left.\mathrm{Zn}\left(\mathrm{H}_{2} \mathbf{L}\right) \mathbf{B}\right)$, and their sum is slightly higher than those of the binary species around the physiological pH (Figure 5). Indeed, the values of $\Delta \log K=$ $\log \beta_{\mathrm{ZnH}_{\mathrm{x}} \mathrm{LB}}-\log \beta_{\mathrm{ZnH}_{\mathrm{x}} \mathrm{L}}-\log \beta_{\mathrm{ZnB}}=0.16(\mathrm{x}=3)$ and $-0.42(\mathrm{x}=2)$ indicate enhanced stability of the ternary complexes [37], especially considering the crowded environment of zinc(II) caused by the large peptide molecule.

Consequently, the complex $\mathrm{ZnH}_{2} \mathbf{L}$ mimics some specific features of MMPs' active centers: the peptide is coordinated to zinc(II) by three imidazole nitrogens, the deprotonation of the zinc-bound water takes place near to the neutral $\mathrm{pH}$-range $(\mathrm{pK}=7.6$ and 8.6 ), and it forms relatively stable ternary complexes with hydroxamic acids. Nevertheless, the zinc binding affinity of the peptide, probably according to its flexible structure, is very modest in comparison with the apo-enzymes. 


\subsection{Copper(II) complexes}

The presence of separated histidines in a peptide chain allow the formation of oligonuclear copper(II) complexes, since the imidazole ring is an efficient anchoring group for copper(II) promoted amide deprotonation [38]. Consequently, in the copper(II)-L system mono-, di- and trinuclear complexes may form. This was confirmed by our ESI-MS data (Figure 6), which indicated the formation of mononuclear $\left(e . g .\left[\mathrm{CuH}_{3} \mathbf{L}\right]^{3+}\right.$ at $\mathrm{m} / \mathrm{z}=588.9$, $\left[\mathrm{CuH}_{-2} \mathbf{L}\right]^{2-}$ at $\left.\mathrm{m} / \mathrm{z}=880.9\right)$, dinuclear $\left(\right.$ e.g. $\left[\mathrm{Cu}_{2} \mathrm{H}_{-4} \mathbf{L}\right]^{2-}$ at $\left.\mathrm{m} / \mathrm{z}=911.3\right)$ and trinuclear $($ e.g. $\left[\mathrm{Cu}_{3} \mathrm{H}_{-6} \mathbf{L}\right]^{2-}$ at $\left.\mathrm{m} / \mathrm{z}=941.8\right)$ species. Therefore, the copper(II) binding ability of $\mathbf{L}$ has been studied by combined pH-metric, UV-Vis, CD, ${ }^{1} \mathrm{H}$ NMR and EPR spectroscopic methods at $3 / 1,2 / 1,1 / 1$, and $1 / 2\left[\mathrm{Cu}^{2+}\right]_{\mathrm{tot}} /[\mathbf{L}]_{\mathrm{tot}}$ ratios. Since the complexes with different nuclearity may have several protonation states, the copper(II)-L system presents a complicated, but rather obvious speciation behavior. The comparative evaluation of the experimental data indicated the formation of 7 mononuclear, 6 dinuclear and 7 trinuclear species (Table 1, Figure 7). Below pH 5 two mononuclear complexes $\mathrm{CuH}_{4} \mathbf{L}$ and $\mathrm{CuH}_{3} \mathbf{L}$ are formed in a strongly overlapping manner (Figure 7), therefore only the spectroscopic parameters of the latter can be determined with certainty $\left(\lambda^{\mathrm{d}-\mathrm{d}}{ }_{\max } \sim 695 \mathrm{~nm}, \mathrm{~g}_{/ /}=2.285, \mathrm{~A}_{/ /}=160 \mathrm{G}\right.$, low intensity $\mathrm{CD}$ spectrum). These data indicate $\left\{2 \mathrm{~N}_{\mathrm{im}}\right\}$ coordination in $\mathrm{CuH}_{3} \mathbf{L}$, with the possibility of additional carboxylate coordination. Between $\mathrm{pH}$ 5-7 the complex $\mathrm{CuH}_{2} \mathbf{L}$ dominates in the solution. Its spectroscopic parameters $\left(\lambda^{\mathrm{d}-\mathrm{d}}{ }_{\max } \sim 630 \mathrm{~nm}, \mathrm{~g}_{/ /}=2.260, \mathrm{~A}_{/ /}=173 \mathrm{G}\right.$, low intensity CD spectrum) suggest $\left\{3 \mathrm{~N}_{\mathrm{im}}\right\}$ coordination. This is confirmed by the ${ }^{1} \mathrm{H}$ NMR spectra of the peptide detected with increasing concentration of copper(II) (Figure 8). At $\left[\mathrm{Cu}^{2+}\right] /[\mathbf{L}]=0.01$ ratio, only the $\mathrm{C} 2-\mathrm{H}$ and $\mathrm{C} 5-\mathrm{H}$ protons of the three imidazole rings are strongly broadened. On the other hand, at $\left[\mathrm{Cu}^{2+}\right] /[\mathbf{L}]=0.09$ ratio, only the lysine signals remained relatively well resolved (Figure 8). These facts indicate that the central metal ion has $\left\{3 \mathrm{~N}_{\mathrm{im}}\right\}$ type 
coordination in $\mathrm{CuH}_{2} \mathbf{L}$, and the two protons are located on the terminal lysine $\varepsilon$-amino groups. The $\log \mathrm{K}$ value for the reaction $\mathrm{Cu}^{2+}+\mathrm{H}_{2} \mathbf{L}=\mathrm{CuH}_{2} \mathbf{L}(\log \mathrm{K}=7.77)$ agrees well with the constants available for $\left\{3 \mathrm{~N}_{\mathrm{im}}\right\}$ coordinated copper(II)-peptide complexes with different size of macrochelate rings ( $\log \mathrm{K}=8.08$ for Ac-HAHVH-NH $\mathrm{N}_{2}$ [31], $\log \mathrm{K}=7.80$ for AcHAAHVVH-NH ${ }_{2}$ [30], $\log \mathrm{K}=7.48$ Ac-(HNPGYP) $)_{3}-\mathrm{NH}_{2}$ [39]). These data also indicate that the consideration of additional carboxylate coordination is not necessary to account for the observed stability.

Between pH 6-10 four successive deprotonations have been observed, which result in characteristic changes on the UV-Vis, CD and EPR spectra, indicating the increase of the ligand-field strength around the metal ion. At $\mathrm{pH} 8.2$ and $9.5 \mathrm{Cu} \mathbf{L}$ and $\mathrm{CuH}_{-1} \mathbf{L}$ are the dominant species (Figure 7). Their spectroscopic parameters $\left(\lambda_{\max }^{\mathrm{d}-\mathrm{d}} \sim 585\right.$ and $525 \mathrm{~nm}, \mathrm{~g}_{/ /}=$ 2.225 and 2.195, $\mathrm{A}_{/ /}=172$ and $190 \mathrm{G}$, intense $\mathrm{CD}$ spectra) indicate $\left\{\mathrm{N}_{\mathrm{im}}, 2 \mathrm{~N}^{-}\right\}$and $\left\{\mathrm{N}_{\mathrm{im}}, 3 \mathrm{~N}^{-}\right\}$ type coordination, respectively. The UV-Vis (Table 1), CD (Fig. S2, see Supplementary Data) and EPR (Fig. S6) spectra of $\mathrm{CuH}_{-1} \mathbf{L}$ and $\mathrm{CuH}_{-2} \mathbf{L}$ are nearly identical, indicating that the last detected deprotonation do not affect the coordination sphere of copper(II). Indeed, the observed $\mathrm{pK}$ value (10.27) is close to one of the lysine $\mathrm{pK}$ in the free peptide (Table 1).

Although $\mathrm{CuH}_{2} \mathbf{L}$ has much higher thermodynamic stability than $\mathrm{ZnH}_{2} \mathbf{L}$, the amide coordination ceases the analogy between the copper(II) binding of $\mathbf{L}$ and the recently identified copper(II) containing variants of MMPs already at $\mathrm{pH} 7$.

The side chains of peptide $\mathbf{L}$ can not provide high affinity binding for two or three copper ions, consequently the oligonuclear complexes are formed by the deprotonation and coordination of amide nitrogens. Indeed, in presence of metal ion excess the spectroscopic data, especially the intense $\mathrm{CD}$ band detected around $280 \mathrm{~nm}$, corresponding to the copper(II)-amide charge transfer transition, indicate the coordination of amide nitrogens at nearly two units lower $\mathrm{pH}$ than observed in the equimolar system (Figure 9). The successive 
formation of the complexes are strongly overlapped (Figure S3), and the presence of several binding isomers can be expected in most of the cases, i.e. clear binding site assignment cannot be made, although $\left\{\mathrm{N}_{\mathrm{im}}, \mathrm{N}^{-}\right\},\left\{\mathrm{N}_{\mathrm{im}}, 2 \mathrm{~N}^{-}\right\}$, and $\left\{\mathrm{N}_{\mathrm{im}}, 3 \mathrm{~N}^{-}\right\}$coordination environment can be expected around the copper(II) ions. All oligonuclear complexes have detectable, but unresolved EPR spectra (Figs. S4. and S5), indicating weakly interacting metal ions, as expected based on the well separated His units within the peptide chain.

\subsection{Kinetic study}

As stated above, the complex $\mathrm{ZnH}_{2} \mathbf{L}$ mimics some specific features of MMPs' active centers, e.g. the formation of zinc-bound hydroxide ion in the neutral $\mathrm{pH}-$ range, which is the key feature of zinc promoted hydrolytic processes. Therefore we performed kinetic study to screen the hydrolytic activity of the zinc(II)-L system, by using $p$-nitrophenyl acetate (pNPA), a generally used activated substrate. The presented kinetic data were corrected with the autohydrolysis of pNPA. The $\mathrm{pH}$ - rate constant profile (Figure 1) indicates that important hydrolytic activity developed between $\mathrm{pH} 7$ and 9, which can be related to the mono- and dihydroxo complexes ( $\mathrm{ZnHL}$ and $\mathrm{ZnL}$ ). Indeed, between $\mathrm{pH} 7.4$ and 9.2 the observed $\mathrm{k}_{\mathrm{obs}, \text { corr }}$ values can be well reproduced by the equation $\mathrm{k}_{\mathrm{obs}, \text { corr }}=\mathrm{k}_{\mathrm{ZnHL}} \times[\mathrm{ZnHL}]+\mathrm{k}_{\mathrm{ZnL}} \times[\mathrm{ZnL}]$ (dashed line in Figure 1), where the individual second-order rate constants are $\mathrm{k}_{\mathrm{ZnHL}}=0.24 \mathrm{M}^{-1} \mathrm{~s}^{-1}$ and $\mathrm{k}_{\mathrm{ZnL}}=1.44 \mathrm{M}^{-1} \mathrm{~s}^{-1}$. This is also confirmed by the linear dependence of $\mathrm{k}_{\mathrm{obs}, \text { corr }}$ on the sum of ZnHL and ZnL concentrations at pH 9.19 (Figure S7). Since the deprotonation of ZnL above $\mathrm{pH} 9.2$ do not affect the coordination environment of zinc(II), the complexes $\mathrm{ZnH}_{-1} \mathbf{L}$ and $\mathrm{ZnH}_{-2} \mathbf{L}$ are probably also active, but their formation is out of the biologically relevant $\mathrm{pH}-$ range.

In order to have better insight into the mechanism, the initial rate of hydrolysis was measured as the function of substrate concentration at $\mathrm{pH}$ 8.7. As shown in Figure 10, above 
40-fold excess of substrate, saturation was observed. This indicates a fast pre-equilibrium related to the formation of the catalytically active (catalyst-substrate) adduct, followed by the rate determining transformation of the substrate within this adduct. The treatment of the data in Figure 9, using the Michaelis-Menten model, yielded $\mathrm{k}_{\mathrm{cat}}=0.0090 \mathrm{~s}^{-1}$ and $\mathrm{K}_{\mathrm{M}}=0.0077 \mathrm{M}$.

The zinc-bound hydroxide ion may operate both as direct nucleophile or general base catalyst. Although, we are not able to differentiate these processes, in the present case general base catalysis seems to be more probable. It is not clear, what is the reason of the six-fold lower activity of $\mathrm{ZnHL}$ as compared to $\mathrm{ZnL}$, since they may operate in the same way. May be the first hydroxide is engaged in a hydrogen bond.

Despite the frugality of the present peptide model, the observed hydrolytic activity for $\mathrm{ZnHL}$ and $\mathrm{ZnL}$ is somewhat higher then those of other simple enzyme mimicks (Table 2), especially considering the $\mathrm{pKs}$ of zinc-bound water deprotonation. However, the de novo designed hydrolytic metalloenzyme with similar $\left\{3 \mathrm{~N}_{\mathrm{im}}, \mathrm{OH}^{-}\right\}$coordinated catalytic centre [43] possesses higher activity, probably due to the higher preorganization of the active site.

\section{Conclusions}

The presently studied hexadecapeptide (Ac-KAHEFGHSLGLDHSK-NH $\mathrm{N}_{2}, \mathbf{L}$ ) is identical with the catalytic zinc(II) binding sequence (197-213) of human MMP-13. This part of the protein is tightly engaged within the tertiary structure, while the model peptide is virtually unstructured in aqueous solution. As a consequence, its zinc(II) and copper(II) binding affinity is rather modest in comparison with the apo-enzymes. Nevertheless, the zinc(II)-L system mimics some basic features of the MMP active sites: the main species around $\mathrm{pH} 7\left(\mathrm{ZnH}_{2} \mathbf{L}\right)$ possesses $\left\{3 \mathrm{~N}_{\mathrm{im}}, \mathrm{H}_{2} \mathrm{O}\right\}$ coordination environment, the deprotonation of the zinc-bound water takes place near to the physiological $\mathrm{pH}$, it forms relatively stable 
ternary complexes with hydroxamic acids, and the species $\mathrm{ZnH}_{2} \mathbf{L}(\mathrm{OH})$ and $\mathrm{ZnH}_{2} \mathbf{L}(\mathrm{OH})_{2}$ have notable hydrolytic activity between $\mathrm{pH}$ 7-9.

\section{Acknowledgements}

This work was supported by the Hungarian Scientific Research Found (OTKA K101541).

\section{References}

[1] C. Harford, B. Sarkar, Acc. Chem. Res. 30 (1997) 123-130.

[2] G.L. Millhauser, Accounts of Chemical Research 37 (2004) 79-85.

[3] N. Camerman, A. Camerman, B. Sarkar, B. Can. J. Chem. 54 (1976) 1309-1316.

[4] Farkas, E.; Sóvágó, I.; Kiss, T.; Gergely, A. J. Chem. Soc., Dalton Trans. 1984, 611-616.

[5] T. Gajda, B. Henry, A. Aubry, J.-J. Delpuech, Inorg. Chem. 35 (1996) 586-593.

[6] C.S. Burns, E. Aronoff-Spencer, G. Legname, S.B. Prusiner, W.E. Antholine, G.J. Gerfen, J. Peisach, G.L. Millhauser, Biochemistry 42 (2003) 6794-6803

[7] D. Valensin, M. Luczkowski, F.M. Mancini, A. Legowska, E. Gaggelli, G. Valensin, K. Rolka, H. Kozlowski, Dalton Transaction (2004) 1284-1293.

[8] K. Ösz, Z. Nagy, G. Pappalardo, G. Di Natale, D. Sanna, G. Micera, E. Rizzarelli, I. Sóvágó, Chem. Eur. J. 13 (2007) 7129-7143.

[9] D. Valensin, F. Camponeschi, M. Luczkowski, M.C. Baratto, M. Remelli, G. Valensin, H. Kozlowski, Metallomics 3 (2012) 292-302.

[10] A. Kolozsi, A. Jancsó, N.V. Nagy, T. Gajda, J. Inorg. Biochem. 103 (2009) 940-947.

[11] Z. Paksi, A. Jancsó, F. Pacello, N.V. Nagy, A. Battistoni, T. Gajda, J. Inorg. Biochem. 102 (2008) 1700-1710.

[12] D. Árus, A. Jancsó, D. Szunyogh, F. Matyuska, N.V. Nagy, E..Hoffmann, T.

Körtvélyesi, T. Gajda , J. Inorg. Biochem. 106 (2012) 10-18.

[13] D. Witkowska, D. Valensin, M. Rowinska-Zyrek, A. Karafova, W. Kamysz, H. Kozlowski, J. Inorg. Biochem. 107 (2012) 73-81.

[14] D. Valensin, F. M. Mancini, M. Luczkowski, A. Janicka, K. Wisniewska, E. Gaggelli, G. Valensin, L. Lankiewicz, H. Kozlowski, J. Chem. Soc. Dalton Trans. (2004) 16-22.

[15] M.A. Zoroddu, M. Peana, T. Kowalik-Jankowska, H. Kozlowski, M. Costa, J. Inorg. Biochem. 98 (2004) 931-939, 
[16] A. Jancsó, A. Kolozsi, B. Gyurcsik, N.V. Nagy, T. Gajda, J. Inorg. Biochem. 103 (2009) $1634-1643$.

[17] M. Mylonas, G. Malandrinos, J. Plakatouras, N. Hadjiliadis, K.S. Kasprzak, A. Krezel, W. Bal Chem. Res. Toxicol. 14 ( 2001) 1177-1183.

[18] N.E. Grossoehme, S. Akilesh, M.L. Guerinot, D.E. Wilcox, Inorg. Chem. 45 (2006) 8500-8508.

[19] M.D. Sternlicht, Z. Werb, Ann. Rev. Cell Development Biol. 17 (2001) 463-516.

[20] C. Tallant, A. Marrero, F.X. Gomis-Rüth, Biochim. Biophys. Acta 1803 (2010) 20-28.

[21] I. Massova, L.P. Kotra, R. Fridman, S. Mobashery, The FASEB Journal 12 (1998) $1075-$ 1095 .

[22] R.P. Verma, C. Hansch, Bioorg. Med. Chem. 15 (2007) 2223-2268.

[23] M. Heitzer, A. Hallmann, J. Biol. Chem. 277 (2002) 28280-28286.

[24] E. Kaiser, R.L. Colescott, C.D. Bossinger, P.I. Cook, Anal. Biochem. 34 (1970) 595598.

[25] F.J.C. Rosotti, H. Rosotti, The determination of stability constants, McGraw-Hill Book Co., New York, 1962, p. 149.

[26] E. Högfeldt, Stability Constants of Metal-Ion Complexes, Part A. Inorganic Ligands, Pergamon, New York, 1982, p. 32.

[27] L. Zékány, I. Nagypál, G. Peintler, PSEQUAD for chemical equilibria, Technical Software Distributors: Baltimore, MD, 1991.

[28] A. Rockenbauer, L. Korecz, Appl. Magn. Reson. 10 (1996) 29-43.

[29] A. Jancsó, Z. Paksi, N. Jakab, B. Gyurcsik, A. Rockenbauer, T. Gajda, Dalton Trans. (2005) 3187-3194.

[30] S. Rajkovic, Cs. Kállay, R. Serényi G. Malandrinos, N. Hadjiliadis, D. Sanna, I.Sóvágó, Dalton Trans. (2008) 5059-5071.

[31] Cs. Kállay, K. Várnagy, G. Malandrinos, N. Hadjiliadis, D. Sanna, I. Sóvágó, Inorg. Chim. Acta 362 (2009) 935-945.

[32] S.A. Daignault, A.P. Arnold, A.A. Isab, D.L. Rabenstein, Inorg. Chem. 24 (1985) 39843988.

[33] D.L. Rabenstein, S.A. Daignault, A.A. Isab, A.P. Arnold, M.M. Shoukry, J. Am. Chem. Soc. 107 (1985) 6435-6439.

[34] M. Mylonas, A. Krzel, J.C. Plakatouras, N. Hadjiliadis, W. Bal, Bioinorg. Chem. Appl. 2 (2004) 125-140.

[35] E. Khairy, M. Shoukry, M. Khalil, Transition Met.Chem. 21 (1996) 176-180. 
[36] E. Farkas, É. Enyedy, H. Csóka. J. Inorg. Biochem. 79 (2000) 205-211.

[37] M.T. Beck, I. Nagypál, Chemistry of Complex Equilibria, Akadémiai Kiadó (Budapest) and Ellis Horwood Limited Publishers (Chichester), 1990.

[38] I. Sóvágó, K. Ösz, Dalton Trans. (2006) 3841-3854.

[39] P. Stanczak, D. Valensin, P. Juszczyk, Z. Grzonka, C. Migliorini, E. Molteni, G.

Valensin, E. Gaggelli, H. Kozlowski, Biochemistry 44 (2005) 12940-12944.

[40] E. Kimura, T. Shiota, T. Koike, M. Shiro, M. Kodama, J. Am. Chem. Soc. 112 (1990) 5805-5811.

[41] T. Koike, E. Kimura, J. Am. Chem. Soc. 113 (1991) 8935-8941.

[42] J. Aguilar, A. Bencini, E. Berni, A. Bianchi, E.Garcia-Espana, L. Gil, A.Mendoza, L. Ruiz-Ramirez, C. Soriano, Eur. J. Inorg. Chem. (2004) 4061-4071.

[43] M.L. Zastrow, A.F.A. Peacock, J.A. Stuckey, V.L. Pecoraro, Nature Chemistry, 4, (2012) 118-123. 
Table 1. Formation constants of the proton, zinc(II) and copper(II) complexes of $\mathbf{L}$ (estimated errors in parentheses referring to the last digit, $I=0.1 \mathrm{M} \mathrm{NaCl}, T=298 \mathrm{~K}$ ) and the $\lambda_{\max }^{\mathrm{d}-\mathrm{d}}$ value of the copper(II) complexes

\begin{tabular}{|c|c|c|c|c|c|}
\hline $\mathbf{H}_{\mathbf{q}} \mathbf{L}_{\mathbf{r}}$ & $\log \beta_{\mathrm{pqr}}$ & pK & $\mathbf{H}_{\mathbf{q}} \mathbf{L}_{\mathbf{r}}$ & $\log \beta_{\mathrm{pqr}}$ & pK \\
\hline HL & $10.9(2)$ & 10.9 & $\mathrm{H}_{5} \mathbf{L}$ & $40.20(1)$ & 5.86 \\
\hline $\mathrm{H}_{2} \mathbf{L}$ & $20.95(8)$ & 10.05 & $\mathrm{H}_{6} \mathbf{L}$ & $44.28(4)$ & 4.08 \\
\hline $\mathrm{H}_{3} \mathbf{L}$ & $27.94(1)$ & 6.99 & $\mathrm{H}_{7} \mathbf{L}$ & $47.5(1)$ & 3.2 \\
\hline $\mathrm{H}_{4} \mathbf{L}$ & $34.34(1)$ & 6.40 & & & \\
\hline $\mathbf{M}_{\mathrm{p}} \mathbf{H}_{\mathrm{q}} \mathbf{L}_{\mathrm{r}}$ & $\log \beta_{\mathrm{pqr}}$ & $\mathbf{M}_{\mathbf{p}} \mathbf{H}_{\mathbf{q}} \mathbf{L}_{\mathbf{r}}$ & $\log \beta_{\mathrm{pqr}}$ & $\mathbf{M}_{\mathbf{p}} \mathbf{H}_{\mathbf{q}} \mathbf{L}_{\mathbf{r}}$ & $\log \beta_{\mathrm{pqr}}$ \\
\hline $\mathrm{ZnH}_{3} \mathrm{~L}$ & $31.59(4)$ & $\mathrm{ZnL}$ & $9.22(3)$ & $\mathrm{ZnH}_{-2} \mathrm{~L}$ & $-11.5(1)$ \\
\hline $\mathrm{ZnH}_{2} \mathrm{~L}$ & $25.41(3)$ & $\mathrm{ZnH}_{-1} \mathrm{~L}$ & $-0.84(3)$ & $\mathrm{ZnH}_{4} \mathrm{~L}_{2}$ & $49.94(2)$ \\
\hline ZnHL & $17.82(3)$ & & & & \\
\hline $\mathbf{M}_{\mathrm{p}} \mathbf{H}_{\mathrm{q}} \mathbf{L}_{\mathbf{r}}$ & $\log \beta_{p q r}$ & $\lambda^{d-d}{ }_{\max }(\mathrm{nm})$ & $\log \beta_{p q r}$ & $\mathbf{M}_{\mathbf{p}} \mathbf{H}_{\mathbf{q}} \mathbf{L}_{\mathbf{r}}$ & $\lambda^{\mathrm{d}-\mathrm{d}}{ }_{\max }(\mathrm{nm})$ \\
\hline $\mathrm{CuH}_{4} \mathrm{~L}$ & $38.40(2)$ & - & $\mathrm{Cu}_{2} \mathrm{H}_{-4} \mathrm{~L}$ & $-11.61(3)$ & 535 \\
\hline $\mathrm{CuH}_{3} \mathrm{~L}$ & $33.94(1)$ & 695 & $\mathrm{Cu}_{2} \mathrm{H}_{-5} \mathrm{~L}$ & $-21.95(10)$ & 525 \\
\hline $\mathrm{CuH}_{2} \mathrm{~L}$ & $28.72(1)$ & 630 & $\mathrm{Cu}_{2} \mathrm{H}_{-6} \mathrm{~L}$ & $-32.9(2)$ & 525 \\
\hline $\mathrm{CuHL}$ & $21.36(3)$ & 595 & $\mathrm{Cu}_{3} \mathrm{H}_{-2} \mathrm{~L}$ & $10.51(3)$ & 610 \\
\hline $\mathrm{CuL}$ & $13.87(3)$ & 585 & $\mathrm{Cu}_{3} \mathrm{H}_{-3} \mathrm{~L}$ & $4.06(2)$ & 610 \\
\hline $\mathrm{CuH}_{-1} \mathrm{~L}$ & $5.02(3)$ & 525 & $\mathrm{Cu}_{3} \mathrm{H}_{-4} \mathrm{~L}$ & $-2.91(2)$ & 595 \\
\hline $\mathrm{CuH}_{-2} \mathrm{~L}$ & $-5.25(4)$ & 525 & $\mathrm{Cu}_{3} \mathrm{H}_{-5} \mathrm{~L}$ & $-10.49(2)$ & 570 \\
\hline $\mathrm{Cu}_{2} \mathrm{~L}$ & $19.88(2)$ & - & $\mathrm{Cu}_{3} \mathrm{H}_{-6} \mathrm{~L}$ & $-19.37(2)$ & 550 \\
\hline $\mathrm{Cu}_{2} \mathrm{H}_{-2} \mathrm{~L}$ & $6.12(2)$ & 590 & $\mathrm{Cu}_{3} \mathrm{H}_{-7} \mathrm{~L}$ & $-29.63(3)$ & 540 \\
\hline $\mathrm{Cu}_{2} \mathrm{H}_{-3} \mathrm{~L}$ & $-2.25(3)$ & 545 & $\mathrm{Cu}_{3} \mathrm{H}_{-8} \mathrm{~L}$ & $-39.47(2)$ & 530 \\
\hline
\end{tabular}


Table 2. Formation constants of the proton and zinc(II) complexes of benzohydroxamic acid (B) and its ternary complexes with $\mathbf{L}$ (estimated errors in parentheses referring to the last digit, $I=0.1 \mathrm{M} \mathrm{NaCl}, T=298 \mathrm{~K})$.

\begin{tabular}{|c|c|c|}
\hline $\mathbf{M}_{\mathbf{p}} \mathbf{H}_{\mathbf{q}} \mathbf{L}_{\mathbf{r}} \mathbf{B}_{\mathbf{s}}$ & $\log \beta_{\mathbf{p q r s}}$ & $\mathbf{p K} / \log \mathbf{K}$ \\
\hline $\mathrm{HB}$ & $8.71(1)$ & $\mathrm{pK}=8.71$ \\
\hline $\mathrm{MB}$ & $4.97(3)$ & $\log \mathrm{K}_{1}=4.97$ \\
\hline $\mathrm{MB}_{2}$ & $9.20(4)$ & $\log \mathrm{K}_{2}=4.23$ \\
\hline $\mathrm{M}\left(\mathrm{H}_{3} \mathrm{~L}\right) \mathrm{B}$ & $36.72(6)$ & $\log \mathrm{K}_{\mathrm{ZnH}_{3} \mathrm{~L}+\mathrm{B}}=4.78$ \\
\hline $\mathrm{M}\left(\mathrm{H}_{2} \mathrm{~L}\right) \mathrm{B}$ & $29.96(3)$ & $\log \mathrm{K}_{\mathrm{ZnH}_{2} \mathrm{~L}+\mathrm{B}}=4.55$ \\
\hline
\end{tabular}


Table 3. Kinetic data of selected catalysts for $p$-nitrophenyl acetate hydrolysis at $25{ }^{\circ} \mathrm{C}$.

\begin{tabular}{|c|c|c|c|c|}
\hline Catalyst & $\mathrm{pK}_{\mathrm{H}_{2} \mathrm{O}}{ }^{1}$ & $\mathrm{k}_{\text {cat }} / \mathrm{K}_{\mathrm{M}}\left(\mathrm{M}^{-1} \mathrm{~s}^{-1}\right)$ & $\mathrm{k}_{\text {complex }}\left(\mathrm{M}^{-1} \mathrm{~s}^{-1}\right)$ & Ref. \\
\hline $\mathrm{Zn}\left(\mathrm{H}_{2} \mathbf{L}\right)(\mathrm{OH})$ & 7.59 & & 0.24 & this work \\
\hline $\mathrm{Zn}\left(\mathrm{H}_{2} \mathbf{L}\right)(\mathrm{OH})_{2}$ & 8.60 & $\sim 1.2($ at $\mathrm{pH} 8.7)$ & 1.44 & this work \\
\hline $\mathrm{Zn}[12]$ aneN & & & \\
\hline $\mathrm{Zn}[12] \mathrm{aneN}_{4}(\mathrm{OH})$ & 7.20 & & 0.041 & {$[40]$} \\
\hline $\mathrm{Zn}_{2} \mathrm{~A}(\mathrm{OH})^{2}$ & 7.90 & & 0.11 & {$[41]$} \\
\hline $\mathrm{Zn}_{2} \mathrm{~A}(\mathrm{OH})_{2}{ }^{2}$ & 9.80 & & 0.07 & {$[42]$} \\
\hline $\mathrm{Zn}\left(\mathrm{Hg}(\mathrm{B})_{3}\right)(\mathrm{OH})^{3}$ & 8.80 & $17.6($ at $\mathrm{pH} 9.0)$ & & {$[42]$} \\
\hline
\end{tabular}

${ }^{1} \mathrm{pK}$ of zinc-bound water deprotonation

${ }^{2} \mathrm{~A}=2,6,9,12,16$-pentaaza-[17] $(2,9)(1,10)$ phenanthrolinophane

${ }^{3} \mathrm{~B}=$ Ac-GLKALEEKCKALEEKLKALEEKHKALEEKG-NH ${ }_{2}$ 


\section{Legend}

Figure 1. Speciation diagram of the zinc(II)-L system $\left(\left[\mathrm{Zn}^{2+}\right]=[\mathbf{L}]=0.001 \mathrm{M}, \mathrm{T}=298 \mathrm{~K}, I\right.$ $=0.1 \mathrm{M} \mathrm{NaCl})$ and the $\mathrm{pH}-\mathrm{k}_{\mathrm{obs}, \text { corr }}$ profile $(\square)$ of the pNPA hydrolysis $\left(\left[\mathrm{Zn}^{2+}\right]=[\mathbf{L}]=0.00053\right.$ $\mathrm{M},[\mathrm{pNPA}]=0.001 \mathrm{M}$ ). The dashed line represents the calculated $\mathrm{k}_{\mathrm{obs}, \mathrm{corr}}$ values (see text).

Figure 2: Calculated (upper) and measured (lower) ESI-MS spectra of the $\left[\mathrm{ZnH}_{2} \mathbf{L}+2 \mathrm{H}_{2} \mathrm{O}\right]^{2+}$ (A) and $\left[\mathrm{ZnH}_{3} \mathbf{L}+2 \mathrm{H}_{2} \mathrm{O}\right]^{3+}(\mathbf{B})$ complexes.

Figure 3: The pH-dependence of the ${ }^{1} \mathrm{H}-\mathrm{NMR}$ spectra of $\mathbf{L}$ in the presence and absence of equimolar zinc(II) $\left(\left[\mathrm{Zn}^{2+}\right]=[\mathbf{L}]=0.0028 \mathrm{M}\right)$.

Figure 4: The change of ${ }^{1} \mathrm{H}-\mathrm{NMR}$ spectra of $\mathbf{L}$ at $\mathrm{pH}=7.4$ upon zinc(II) addition ([L]= $0.0057 \mathrm{M})$.

Figure 5. Calculated competition plot between the zinc(II) complexes of $\mathbf{L}, \mathbf{B}$ and their ternary species $\left([\mathbf{L}]=\left[\mathrm{Zn}^{2+}\right]=0.001 \mathrm{M},[\mathbf{B}]=0.002 \mathrm{M}\right)$

Figure 6: Calculated (upper) and measured (lower) ESI-MS spectra of $\left[\mathrm{CuH}_{3} \mathbf{L}\right]^{3+}(\mathbf{A}),[\mathrm{CuH}$ $\left.{ }_{2} \mathbf{L}\right]^{2-}(\mathbf{B}),\left[\mathrm{Cu}_{2} \mathrm{H}_{-4} \mathbf{L}\right]^{2-}(\mathbf{C})$ and $\left[\mathrm{Cu}_{3} \mathrm{H}_{-6} \mathbf{L}\right]^{2-}(\mathbf{D})$ complexes

Figure 7. Speciation diagram of the copper(II)-L system $\left(\left[\mathrm{Cu}^{2+}\right]=[\mathbf{L}]=0.001 \mathrm{M}, \mathrm{T}=298 \mathrm{~K}\right.$, $I=0.1 \mathrm{M} \mathrm{NaCl})$.

Figure 8: The change of ${ }^{1} \mathrm{H}-\mathrm{NMR}$ spectra of $\mathbf{L}$ at $\mathrm{pH}=6.7$ upon copper(II) addition ([L] = $0.0057 \mathrm{M})$.

Figure 9: $\mathrm{pH}$ dependence of the CD intensities at $280 \mathrm{~nm}$ of the copper(II) - $\mathbf{L}$ systems at 1:1 (black square, $\left.[\mathrm{L}]=\left[\mathrm{Cu}^{2+}\right]=0.0012 \mathrm{M}\right), 1: 2\left(\right.$ grey square, $2[\mathrm{~L}]=\left[\mathrm{Cu}^{2+}\right]=0.0018 \mathrm{M}$ ) and 1:3 (open square, $\left.3[\mathrm{~L}]=\left[\mathrm{Cu}^{2+}\right]=0.0018 \mathrm{M}\right)\left[\mathrm{Cu}^{2+}\right] / \mathrm{L}$ ratios $(\mathrm{T}=298 \mathrm{~K})$.

Figure 10: The initial rate of the catalyzed hydrolysis of pNPA as a function of pNPA concentration $\left([\mathbf{L}]=\left[\mathrm{Zn}^{2+}\right]=0.00014 \mathrm{M}, \mathrm{pH}=8.7, \mathrm{~T}=298 \mathrm{~K}\right)$. 


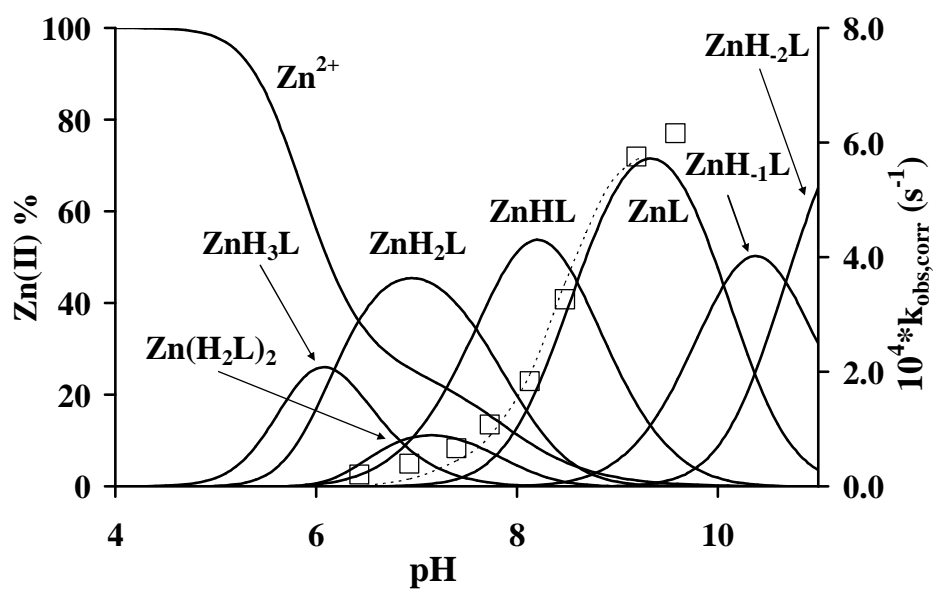

Figure 1. 
A

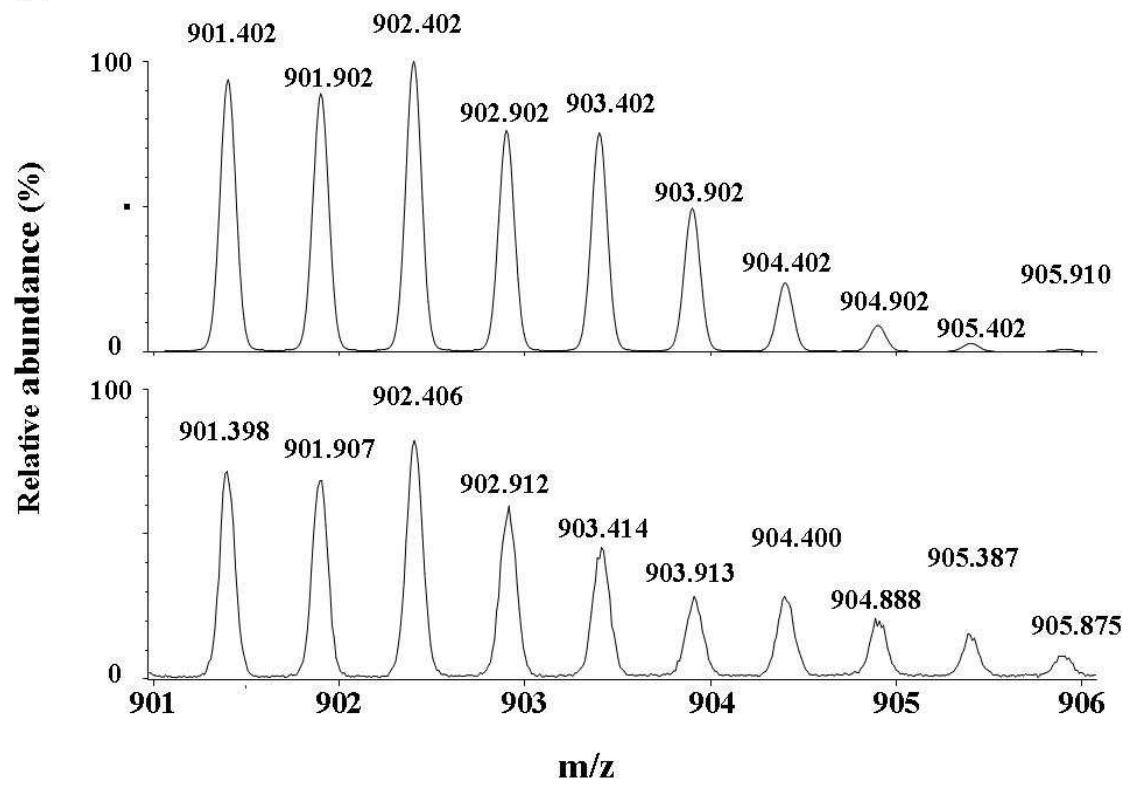

B

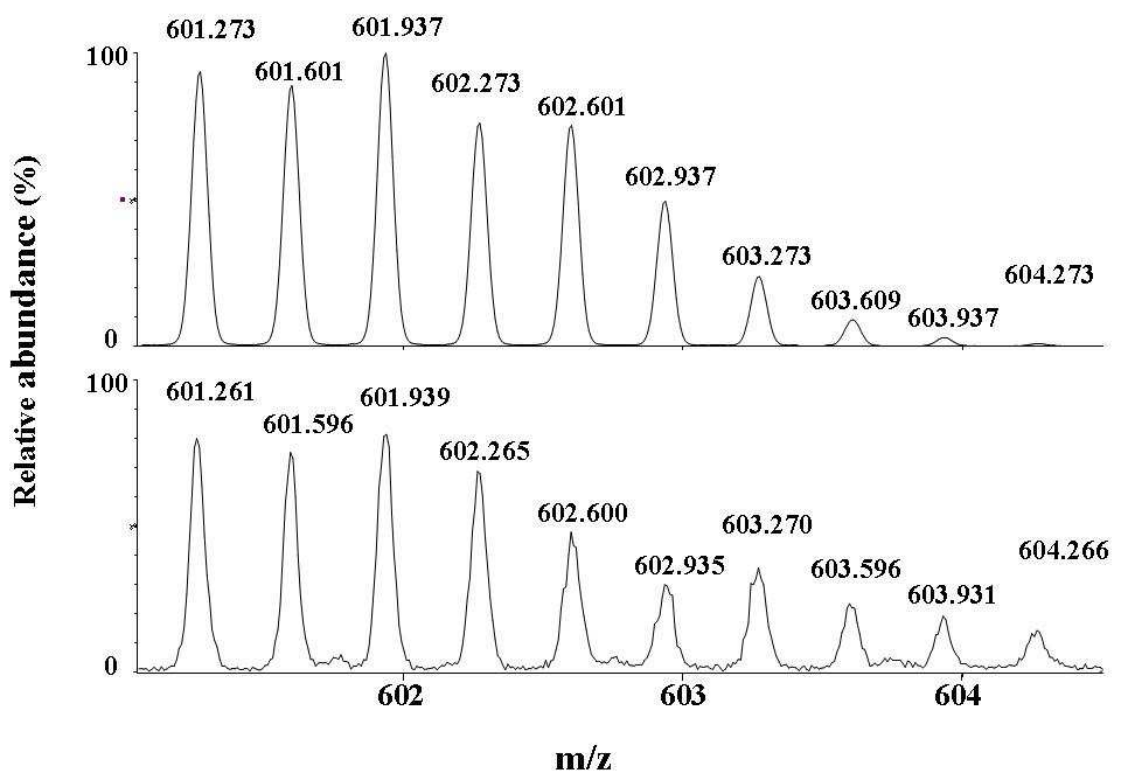

Figure 2 


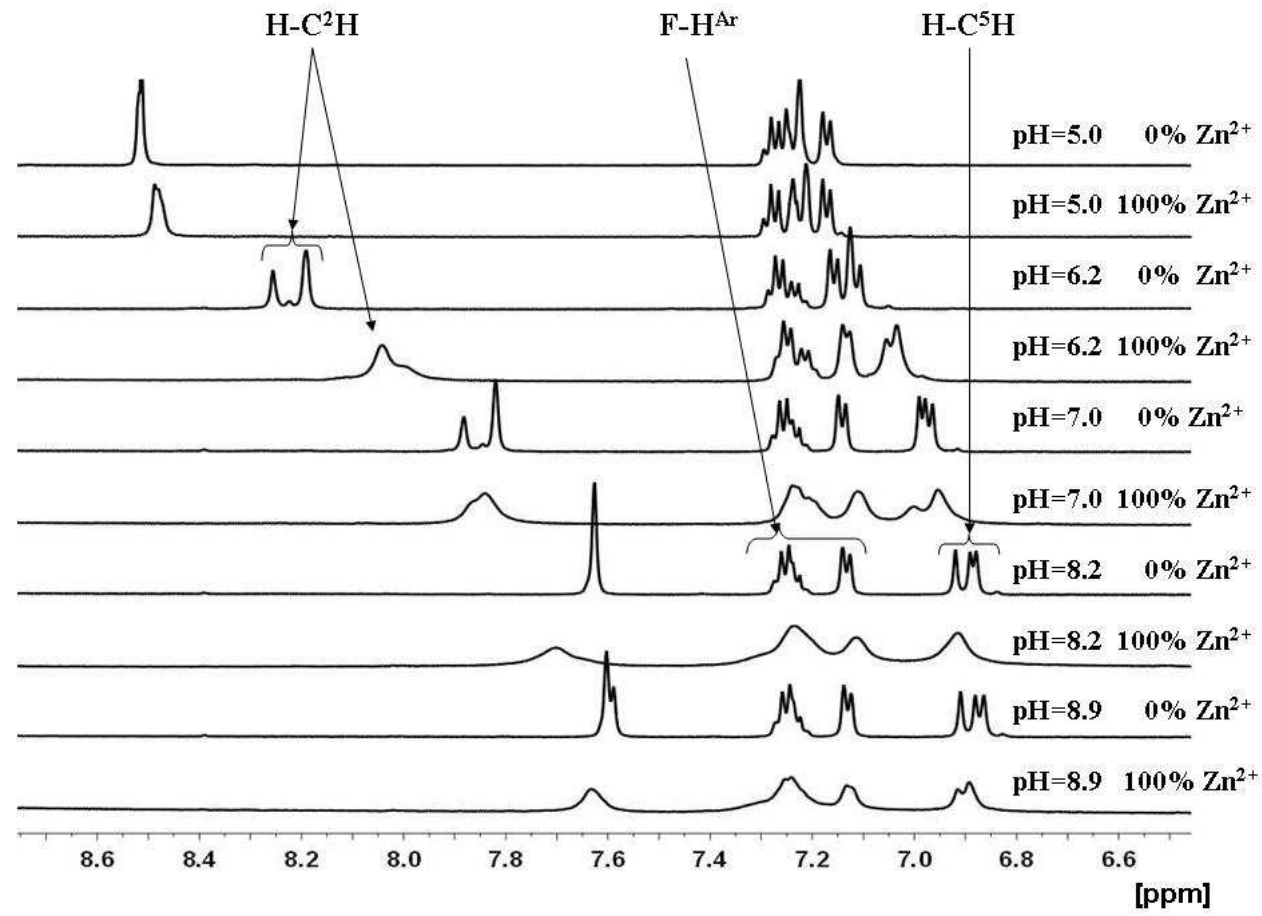

Figure 3 


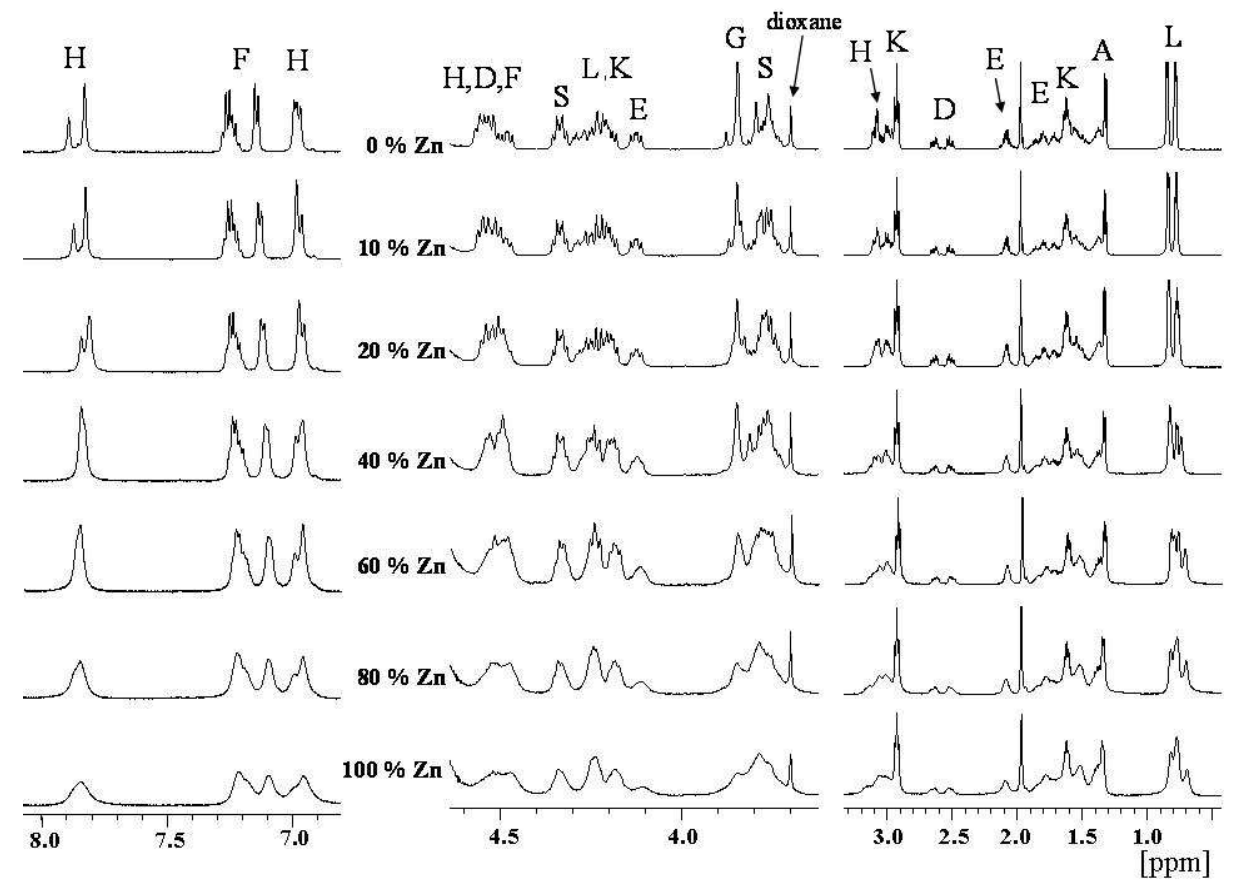

Figure 4 


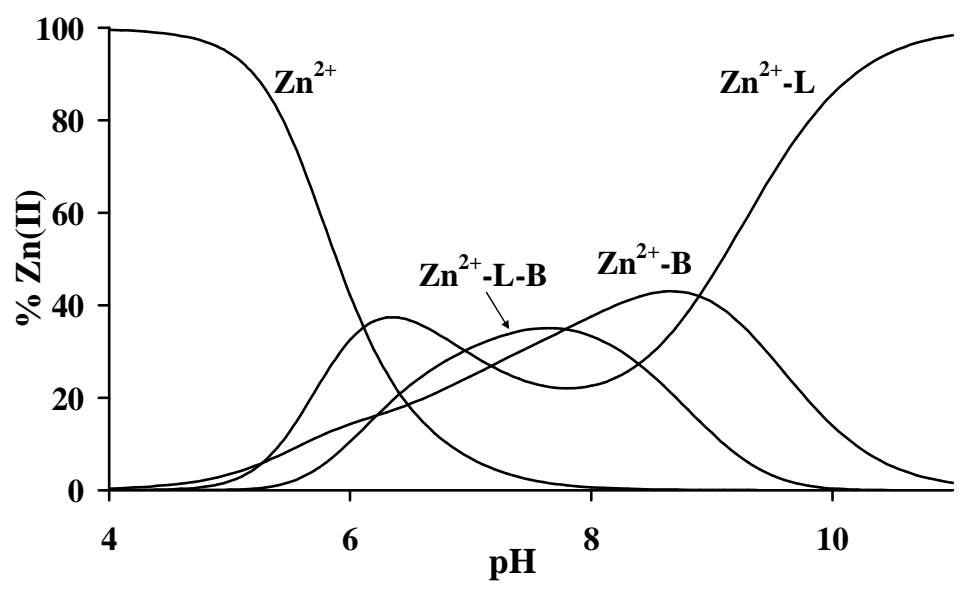

Figure 5 
A

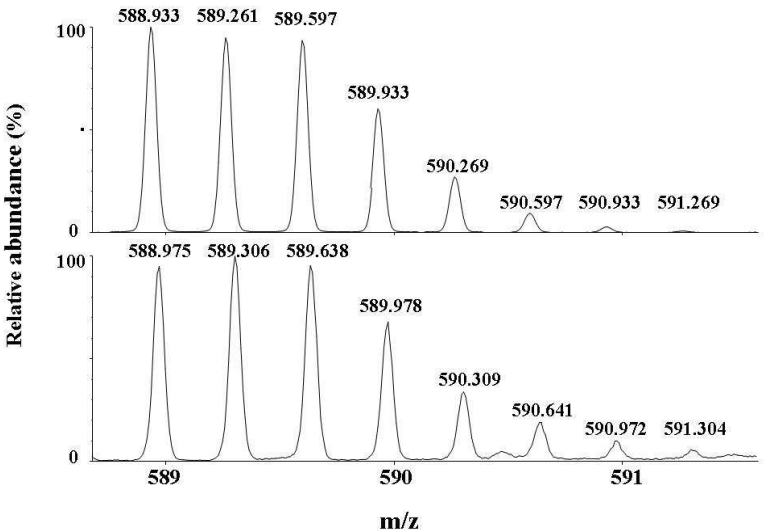

B

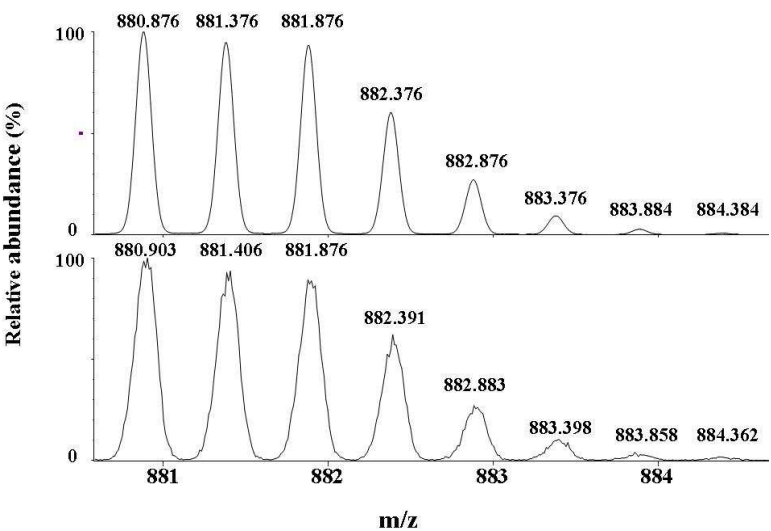

C

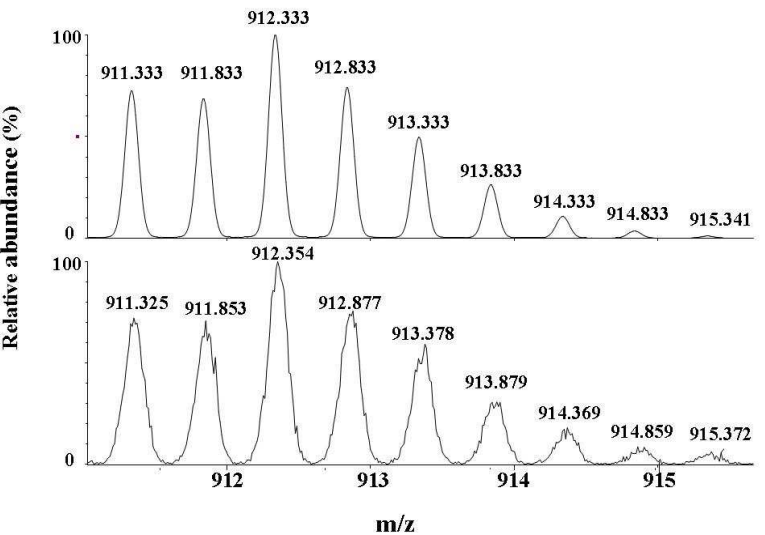

D

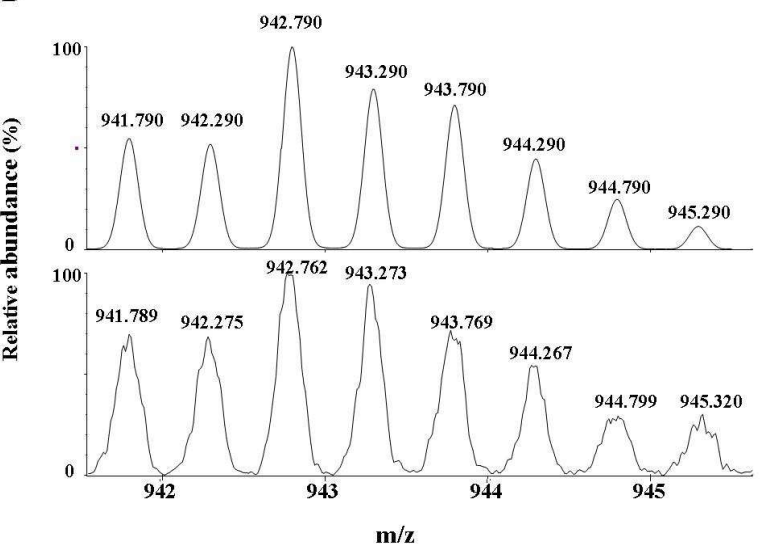

Figure 6 


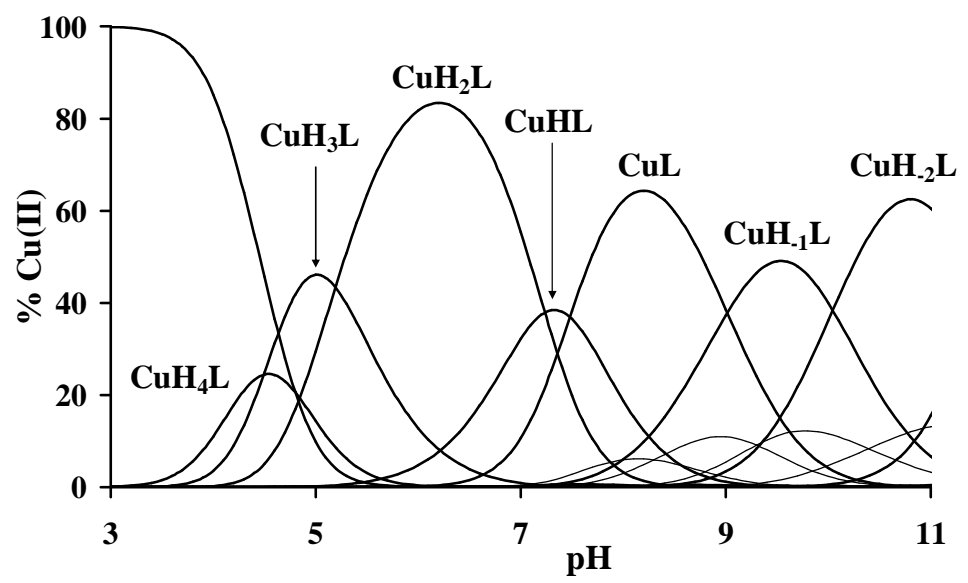

Figure 7 


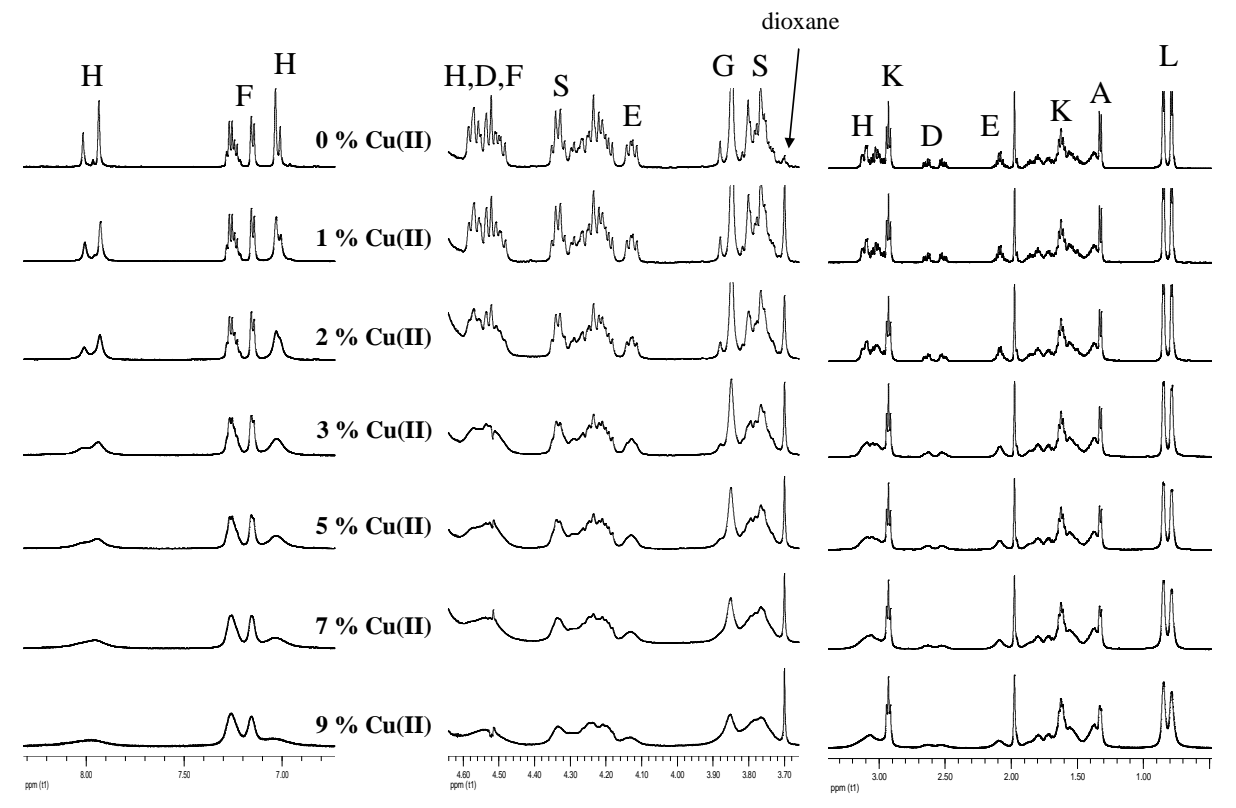

Figure 8. 


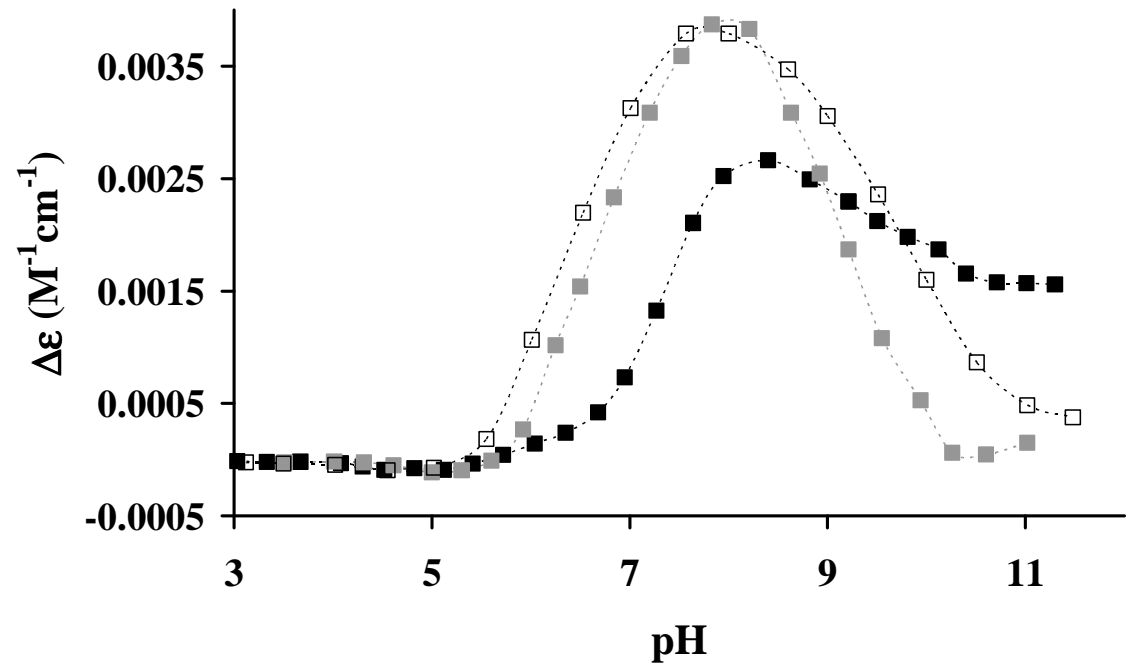

Figure 9. 


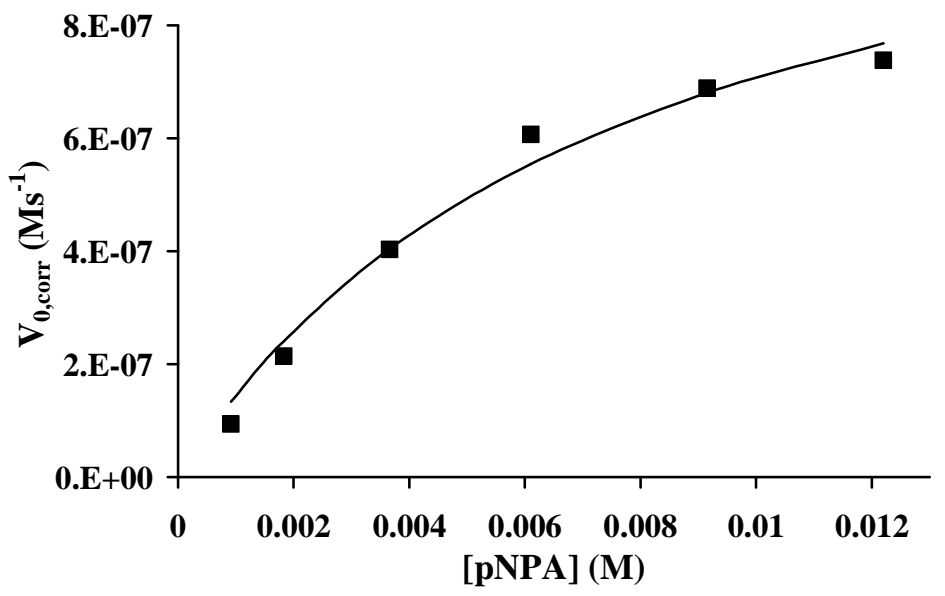

Figure 10 